\title{
Stem form, volume and dry matter production in a twelve-year-old circular Nelder plantation of Populus trichocarpa $\times$ deltoides 'Beaupré'
}

\author{
by J. Steenackers ${ }^{1}$, V. Steenackers ${ }^{2}$, J. Van Acker ${ }^{3}$ and M. Stevens ${ }^{3}$
}

"Model-trees", selected on annual circumference measurements, were sampled at twelve planting distances, with potential growing areas ranging between $9.10 \mathrm{~m}^{2}$ and $72.00 \mathrm{~m}^{2}$.

Every tree, up to a top circumference of $30 \mathrm{~cm}$ was divided into sections with a length of $\pm 45 \mathrm{~cm}$. All sections were weighed (fresh and ovendry) and measured. Annual ring width, bark width and heartwood were measured from $\mathrm{N}$ to $\mathrm{S}$ on every cross section.

Results are given for circumference at breast height, timber height, taper, volume and dry matter production per tree or per hectare, at age 12, up to different top circumferences.
Des “arbres modèles", choisis d'après les mesures annuelles de leur circonférence, ont été échantillonnés selon douze intervalles de plantation correspondant à des superficies d'occupation spatiale potentielle variant de $9.10 \mathrm{~m}^{2}$ à $72.00 \mathrm{~m}^{2}$.

Chaque arbre, jusqu'à une circonférence au fin bout de $30 \mathrm{~cm}$ a été divisé en section de plus ou moins $45 \mathrm{~cm}$ de longueur. Toutes ces sections ont été pesées (humides et anhydres) et mesurées. La largeur des anneaux de croissance, l'épaisseur de l'écorce et le duramen ont été mesurés du nord au sud sur chacune des coupes transversales.

Les résultats présentés comprennent pour des circonférences à hauteur de poitrine, la hauteur de la bille, le volume et la producion de matière anhydre par arbre ou par hectare, à l'âge de douze ans, selon différentes circonférences au fin bout.

\section{Introduction}

The purpose of this investigation was to determine the influence of spacing on stem form, volume and dry matter production of the interamerican poplar clone Populus trichocarpa $\times$ deltoides 'Beaupré', assuming constant growing conditions within the planting area.

\section{Biomass and forestry in Belgium}

Paper factories presently cooperate with the Institute of Forestry and Game Management (I.F.G.M.) of the Flemish Government to address forest biomass production research. The research program consists of establishing experimental plantations at smaller spacings, especially $4 \times 4 \mathrm{~m}$, using a number of interamerican poplar clones, selected at the I.F.G.M., in order to learn more about their production capacity and wood quality for pulp and paper. Poplar clones are planted presently at $8 \times 8 \mathrm{~m}$ spacings for timber production in Belgium.

During the energy crisis of 1977-1983, the Centre for Biomass Studies, at the Laboratory of Wood Technology and Plant Ecology of the State University of Ghent, also did research on biomass production and forestry in Belgium (Schalck et al. 1977 - 1983). The experimental plantation of poplars, as described in this study, was established by this working group, in cooperation with the former Poplar Research Center at Grammont, now the I.F.G.M..

Since 1988, the most important Belgian poplar process-

\footnotetext{
'Assistant at XYLINDUS V.Z.W. (non-profit organization for the evaluation and upgrading of poplar wood in industrial applications), Laboratory of Wood Technology, Coupure links 653, 9000 Ghent, Belgium

${ }^{2}$ Formerly Director of the Institute of Forestry and Game Management, Chairman International Poplar Commission, Voskensstraat 28, 9500 Geraardsbergen, Belgium.

${ }^{3}$ Respectively Assistant and Professor at the University of Ghent, Faculty of Agricultural and Applied Biological Sciences, Laboratory of Wood Technology, Coupure links 653, 9000 Ghent, Belgium
}

ing companies, the Laboratory of Wood Technology at the University of Ghent, and the I.F.G.M., collaborated under the non-profit organization XYLINDUS, and were subsidized by the Flemish Government, to work together to evaluate and improve poplar wood quality (Steenackers J. et al. 1992). The original task was to determine the quality of the wood of the poplar clones selected at the I.F.G.M., among them the well known "Unal-clones".

Industry and forestry landowners, however, also were asking for actual volume production figures of these "new" clones. Due to these questions and the history of the Laboratory of Wood Technology, XYLINDUS started a quantitative study on the "Unal-clones". Preliminary results are presented in this report.

The intention is that XYLINDUS will continue with new experimental plantations, using different planting distances, different clones, different times of thinnings, and different soil types, including marginal farmland and polluted soils.

\section{The plantation}

In the winter of 1979-1980, a circular "Nelder" design plantation was established on the Kaulille Loozerheide Forest of the Bree Forestry Department in the north-eastern part of Belgium, in the region called "De Kempen", at $51^{\circ} 12^{\prime} 40^{\prime \prime}$ northern latitude, $5^{\circ} 32^{\prime} 30^{\prime \prime}$ eastern longitude. Two-year-old sets (dormant unrooted stems) of the poplar clones Populus trichocarpa $\times$ deltoides 'Unal' and 'Beaupré' were used (Schalck et al. 1977 - 1983). Soil analysis classified the site as moderately good for the cultivation of poplar.

The plantation consisted of thirteen concentric circles, of 54 trees per circle for a total of 702 trees (Figure 1). Within this Nelder plot, the interplanting distance increased with increasing distance from the midpoint. Circle 1 represents the inner circle, with the smallest radius and closest planting distance. 


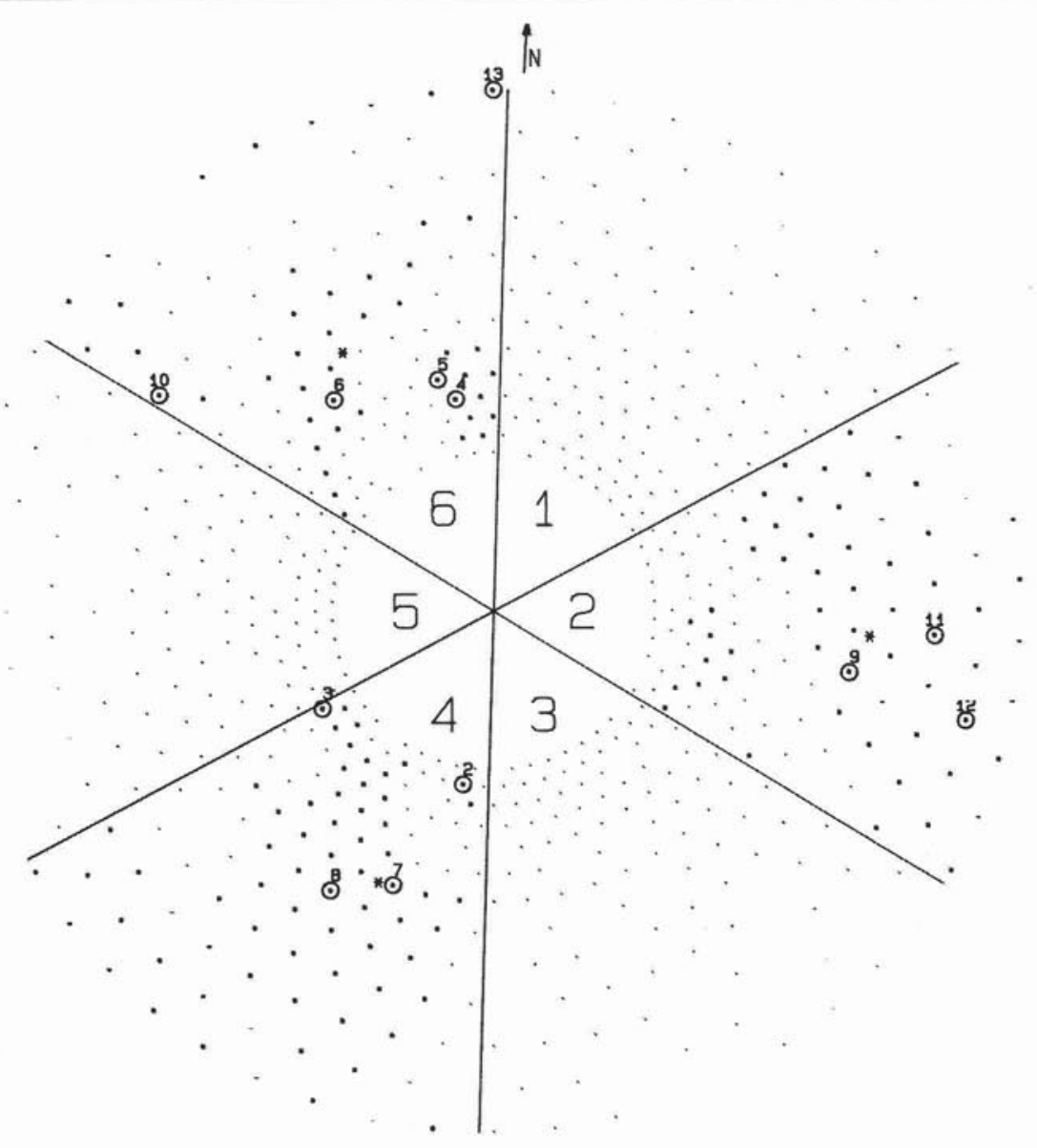

Figure 1. Design of the Nelder plantation at Kaulille (december 1991). Sectors 1, 3 and 5 : small dots : trees 'Unal'; Sectors 2, 4 and 6 : large dots : reference trees 'Beaupré'; encircled large dots : model trees 'Beaupré'; small dots : other trees 'Beaupré'; crosses : places of soil analysis

In normal Nelder designs, type Ia., as developed by Nelder and Bleasdale in Wellesbourne, England, plants are located at every intersection of a circle and a radius. Therefore plants are arranged in an almost rectangular twodimensional array (Nelder 1962). This Nelder designed plantation at Kaulille differs from the original type Ia. as plants are located alternately at the intersections of circles and radii. Therefore, plants are arranged in an almost triangular pattern.

Nelder plantations, established to measure the influence of spacing on tree growth, often are subject of discussions, especially due to the competition between trees at different circles and radii. Trees grown at larger planting distances take growing space at the cost of trees at smaller spacings. Therefore, the potential growing area is not determined by the geometrical midpoints between trees (Faber 1985). However, in our case, the planting distance used at a certain circle never lies more than $5.4 \%$ beneath or above the distance, from a tree at this circle, to the neighbouring trees at the smaller and larger circle. Both factors, namely the triangular planting pattern and the small differences in planting distances, can, in our opinion, be considered as major advances to the oppositions against the dendrometri$\mathrm{cal}$ analysis of Nelder plantations. Therefore, the surface of the hexagon, of which the edges were determined by the midpoints of the triangles formed by a certain tree and every pair of neighbouring trees, was described as the potential growing area (PGA).

Smith (1978) claims that “... Provided there is a wide range of spacing, and individual trees are analysed, highly significant effects on many tree and stand characteristics can be shown efficiently by 49 -tree and Nelder plots. ... Although they are more difficult to establish, the Nelders are very compact and make efficient use of space. Their unique design has a visual and aesthetic impact on the ground and in aerial photographs. They can have an important educational and demonstration value since the visual effects of spacing can be seen clearly as one walks between spokes".

Table 1 presents the dimensions of each circle in terms of its potential growing area, number of trees per hectare and the true planting distance (PT) if planted on the triangle. Both clones, 'Unal' and 'Beaupré', were planted in three sectors, in a symmetrical pattern to the NS- and EWdirection (Figure 1). In the winter of 1980, dead trees were replaced by three-year-old sets. The centre of the experimental plantation, within the smallest circle, was planted with a triangular planting pattern, with $3 \mathrm{~m}$ sides.

Figure 1 illustrates the plantation after the 1991 season; every spot represents a tree. The clone 'Beaupré' was 
Table 1. Dendrometrical results, at an age of 12 years, in relation to spacing.

\begin{tabular}{|c|c|c|c|c|c|c|c|c|c|c|c|c|c|c|c|c|c|c|c|c|}
\hline \multirow[b]{2}{*}{$\mathrm{CN}$} & \multirow[b]{2}{*}{$\begin{array}{c}\text { PGA } \\
\mathrm{m}^{2}\end{array}$} & \multirow[b]{2}{*}{$\mathbf{N}$} & \multirow[b]{2}{*}{$\begin{array}{l}\text { PT } \\
\text { m }\end{array}$} & \multicolumn{8}{|c|}{ Calculated from diameters, without bark } & \multicolumn{9}{|c|}{ Calculated from circumferences } \\
\hline & & & & $\begin{array}{c}\mathrm{CAB} \\
\mathrm{cm}\end{array}$ & $\begin{array}{c}\text { MACI }+2 \\
\mathbf{c m}\end{array}$ & $\begin{array}{c}\text { TH30 } \\
\text { cm }\end{array}$ & $\begin{array}{c}\mathrm{T} 30 \\
\mathrm{~cm} / \mathrm{m}\end{array}$ & $\begin{array}{r}V 30 \\
\mathrm{~m}^{3} \\
\end{array}$ & $\begin{array}{c}\text { VH30 } \\
\mathrm{m}^{3} \\
\end{array}$ & $\begin{array}{c}\text { VH30 } \\
\% \\
\end{array}$ & $\begin{array}{c}\text { V30 } \\
\mathrm{m}^{3} / \mathrm{ha}\end{array}$ & $\begin{array}{c}\mathrm{V} 30\left(^{*}\right) \\
\mathrm{m}^{3}\end{array}$ & $\begin{array}{l}\mathrm{V} 30(*) \\
\mathrm{m}^{3} / \mathrm{ha}\end{array}$ & $\begin{array}{l}\text { DMP30 } \\
\text { tons/ha }\end{array}$ & $\begin{array}{c}\text { FW30 }(*) \\
\text { tons/ha }\end{array}$ & $\begin{array}{c}\text { BARK } \\
\%\end{array}$ & $\begin{array}{c}\text { TH70 } \\
\text { cm }\end{array}$ & $\begin{array}{l}\text { V70 } \\
\mathrm{m}^{3}\end{array}$ & $\begin{array}{c}\text { V70 } \\
\mathrm{m}^{3} / \mathrm{ha}\end{array}$ & $\begin{array}{cc}\text { V70 } & \text { V70 } \\
\mathrm{m}^{3} & \mathrm{~m}^{3} / \mathrm{ha}\end{array}$ \\
\hline 1 & 6.89 & 1451 & 2.82 & - & - & - & - & - & - & - & - & - & - & - & - & - & - & - & - & -- \\
\hline 2 & 9.10 & 1099 & 3.24 & 64.7 & 4.6 & 1586 & 2.5 & 0.334 & 0.065 & 19 & 367 & 0.397 & 436 & 134 & 374 & 8.1 & - & - & - & $0.060 \quad 66$ \\
\hline 3 & 11.14 & 898 & 3.59 & 69.6 & 5.0 & 1748 & 2.5 & 0.396 & 0.073 & 18 & 355 & 0.458 & 411 & 118 & 348 & 9.2 & 147 & 0.059 & 53 & $0.138 \quad 124$ \\
\hline 4 & 13.61 & 735 & 3.96 & 75.0 & 5.4 & 1772 & 2.9 & 0.430 & 0.092 & 21 & 316 & 0.500 & 36 & 102 & 306 & 9.2 & 227 & 0.099 & 73 & $0.225 \quad 165$ \\
\hline 5 & 16.63 & 601 & 4.38 & 78.5 & 5.6 & 1776 & 3.3 & 0.487 & 0.112 & 23 & 293 & 0.566 & & & & 9.4 & 413 & 0.194 & 117 & $0.292 \quad 176$ \\
\hline 6 & 20.36 & 491 & 4.85 & 80.5 & 5.8 & 1820 & 3.2 & 0.525 & 0.070 & 13 & 258 & 0.619 & 30 & 85 & 261 & 10.0 & 499 & 0.237 & 116 & $0.352 \quad 173$ \\
\hline 7 & 24.94 & 401 & 5.37 & 85.1 & 6.1 & 1912 & 3.5 & 0.635 & 0.103 & 16 & 255 & & & 8 & 258 & 9.4 & 729 & 0.379 & 152 & 0.507203 \\
\hline 8 & 30.50 & 328 & 5.93 & 88.8 & 6.3 & 1915 & 3.7 & 0.662 & 0.091 & 14 & 217 & 0.771 & 253 & 75 & 219 & 9.6 & 732 & 0.402 & 132 & $0.538 \quad 176$ \\
\hline 9 & 37.31 & 268 & 6.56 & 94.4 & 6.7 & 1780 & 4.4 & 0.717 & 0.108 & 15 & 192 & & 222 & 65 & 188 & 9.8 & 866 & 0.508 & 136 & $0.642 \quad 172$ \\
\hline 10 & 45.63 & 219 & 7.26 & 100.9 & 7.2 & 1646 & 5.1 & 0.762 & 0.081 & 11 & 167 & 0.911 & 200 & 54 & 173 & 9.8 & 954 & 0.603 & 132 & $0.765 \quad 168$ \\
\hline 11 & 53.76 & 186 & 7.88 & 103.2 & 7.4 & 1731 & 5.0 & 0.792 & 0.124 & 16 & 147 & 0.957 & 178 & 53 & 157 & 9.4 & 954 & 0.616 & 115 & $0.829 \quad 154$ \\
\hline 12 & 58.87 & 170 & 8.24 & 107.8 & 7.7 & 1915 & 5.1 & 0.856 & 0.123 & 14 & 145 & 1.023 & 174 & 53 & 157 & 9.9 & 1002 & 0.663 & 113 & $0.871 \quad 148$ \\
\hline 13 & 72.00 & 139 & 9.12 & 117.4 & 8.4 & 1862 & 5.4 & 1.050 & 0.147 & 14 & 146 & 1.254 & 174 & 51 & 155 & 9.3 & 1228 & 0.924 & 128 & $1.106 \quad 154$ \\
\hline
\end{tabular}

$\mathrm{CN}$, Circle number; PGA, Potential growing area; N, Number of trees per hectare; PT, Planting distance in a triangular pattern; CAB, Circumference at breastheight; MACI+2, Mean annual circumference increment; TH30, Timber height to a top circumference $30 \mathrm{~cm}$; TH70, Timber height to a top circumference $70 \mathrm{~cm}$; T30, Taper to a top circumference $30 \mathrm{~cm}$; V30, Volume to a top circumference $30 \mathrm{~cm}$; V70, Volume to a top circumference $70 \mathrm{~cm}$; VH 30 , Volume of heartwood to a top circumference $30 \mathrm{~cm}$; DMP30, Dry matter production to a top circumference $30 \mathrm{~cm}$, without bark; FW 30 , Fresh weight to a top circumference $30 \mathrm{~cm}$; BARK, The amount of bark; (*), With bark.

planted in sectors 2, 4 and 6; the clone 'Unal' in sectors 1, 3 and 5 . The plantation is still in very good condition despite the close planting distances used. Indeed only 80 trees (i.e. $11.4 \%$ ) have died to date (January 1992). Since replacing failures in 1980, 35 'Beaupré' and 45 'Unal' have died.

\section{Analysis of the "Model-Trees"}

As the clone 'Unal' will not be used any more in poplar plantations in Belgium due to its sensitivity to rust (Steenackers 1991), further discussion is based only on the measurements of the clone 'Beaupré'. In addition, the results of the innermost circle are not considered further, because the plantation in the centre has largely disappeared.

\section{Selection of the Model Trees}

Since 1982, circumferences at breast-height $(1.50 \mathrm{~m})$ were measured annually, except for 1984 . The average circumference of reference trees was calculated for each circle, as an annual average and as an average of the three sectors. A reference tree is defined as a tree surrounded by six other trees, in the year in which the average circumference was determined. Figure 1 shows the present (January 1992) reference trees indicated by a large spot. From this plan, for each circle, trees were selected with the real annual circumference increment curve nearest to the calculated mean annual circumference increment curve, the so called 'model-trees'.

\section{Operations}

January 1992, model-trees were felled and transported to Ghent. Each stem was divided into sections of $\pm 45 \mathrm{~cm}$. The following measurements were made:

(i) weight,

(ii) circumference,

(iii) length,

(iv) annual ring widths, and width of heartwood and bark, from north to south,

(v) circumference inside bark, and

(vi) dry weight.
From previous operations the influence of planting distance on stem form (circumference at breast-height (CAB), timber height (TH) up to different top circumferences (TC), taper, volume (V) and dry matter production (DMP) per tree or per hectare could be determined. All parameters were calculated from diameter measurements, without bark.

The first part of Table 1 presents the results for a top circumference of $30 \mathrm{~cm}$, at an age of 12 years; the second part gives the results for a top circumference of $70 \mathrm{~cm}$, only if they are significantly different.

\section{Circumference at breast-height $(1.50 \mathrm{~m})$}

There was almost no difference between the $\mathrm{CAB}$ at the different planting distances during the first five growing seasons. After 5 years, an average circumference of $42 \mathrm{~cm}$ was reached. Later on the rate of circumference growth increased more rapidly at the wider tree spacings, to reach after 12 years a $C A B=117 \mathrm{~cm}$ at a $P G A$ of $72.00 \mathrm{~m}^{2}$ and a $\mathrm{CAB}=65 \mathrm{~cm}$ at a PGA of $9.10 \mathrm{~m}^{2}$ (Table 1$)$.

\section{Timber Height}

No relationship was found between spacing and timber height at a TC of $30 \mathrm{~cm}$. After 12 years, an average timber height, over all planting distances, of $17.9 \mathrm{~m}$ was reached. However, at larger top circumferences $(>60 \mathrm{~cm})$, the planting distance had great influence on the timber height. Up to now no growth was achieved above $70 \mathrm{~cm}$ circumference at the second circle, while at the outermost circle a height of $12.3 \mathrm{~m}$ was reached (Table 1 ).

\section{Taper}

Taper is determined by the circumference at the base of the stem, by the top circumference and by the timber height. As mentioned before, these three factors are more or less affected by planting distance. Therefore, taper will be affected by planting distance. Regardless of the top circumference, a wider planting distance will result in a greater taper coefficient. After 12 years a PGA of $9.10 \mathrm{~m}^{2}$ will, at a TC of $30 \mathrm{~cm}$, result in a taper coefficient of 2.5 $\mathrm{cm} / \mathrm{m}$; a PGA of $72.00 \mathrm{~m}^{2}$ in $5.4 \mathrm{~cm} / \mathrm{m}$ (Table 1). 


\section{The Amount of Heartwood}

The absolute amount of heartwood and heartwood relative to total stem wood were measured. A closer spacing resulted in a higher relative amount of heartwood, the average being $16 \%$ at a TC of $30 \mathrm{~cm}$ (Table 1). Previous studies (Steenackers J. et al. 1992) on 18 year old trees of the euramerican and interamerican groups showed that 'Beaupré', with $17 \%$ heartwood, is one of the clones with the lowest amount of heartwood, especially in comparison with the euramerican poplar clones such as 'Robusta' (38\% heartwood), 'Gelrica' (48\% of heartwood) and 'Serotina de Champagne' ( $38 \%$ heartwood), that have been planted in Belgium for many years.

\section{Volume Production}

Closer spacings resulted in a smaller stem volume. At a TC of $30 \mathrm{~cm}$ and after 4 years, an average restricted stem volume of 22 litres was reached, irrespective of planting distance. After 7 years, the influence of spacing became apparent. After 12 years, a stem volume of $1.050 \mathrm{~m}^{3}(100$ $\%$ ) was reached in the outermost circle, whereas a volume of $0.334 \mathrm{~m}^{3}(32 \%)$ was attained in the second circle (Table 1).

At a TC of $70 \mathrm{~cm}$, an average restricted stem volume of 46 liters was reached, after only 7 years and starting from the seventh circle. After 12 years, a stem volume of 0.924 $\mathrm{m}^{3}$ was reached at the outermost circle; at the second circle no volume production to a top circumference of $70 \mathrm{~cm}$ was reached.

In terms of volume per hectare, no loss of trees was supposed, i.e. the number of trees per hectare remained unaltered, as we based our analysis only on the reference trees, all being surrounded by six trees. A small TC, combined with a close planting distance resulted in a greater volume production per hectare. After 4 years a closer planting distance resulted in a greater volume production per hectare. After 12 years and at a PGA of $9.10 \mathrm{~m}^{2}$, or 1099 trees per hectare, a plantation will reach a volume production of 367 $\mathrm{m}^{3} / \mathrm{ha}(251 \%)$; at a PGA of $72.00 \mathrm{~m}^{3}$, or 139 trees per hectare, a plantation will reach a volume production of 146 $\mathrm{m}^{3} / \mathrm{ha}(100 \%)$ (Table 1$)$. Note that all volumes are based on diameter measurements under bark. At a TC of $70 \mathrm{~cm}$, differences in volume production per hectare between planting distances are not extreme. After 12 years the maximum volume production, i.e. $152 \mathrm{~m}^{3} / \mathrm{ha}$, remained at a PGA of $24.94 \mathrm{~m}^{2}$.

The mean annual volume increment per hectare (MAVIH) still increased, even after 12 years. This happened independently of TC or planting distance. This means that the current annual volume increment per hectare (CAVIH) still remained higher than the MAVIH (Figure 2). Therefore, rotation age has not been reached yet, for any planting distance. After 12 years at a TC of 30 $\mathrm{cm}$ and a PGA of $9.10 \mathrm{~m}^{2}$, the MAVIH amounts to 31 $\mathrm{m}^{3} /$ ha/year, at a PGA of $72 \mathrm{~m}^{2} 12 \mathrm{~m}^{3} /$ ha/year.

The CAVIH, at a TC of $30 \mathrm{~cm}$, has however already reached its maximum at 9 years, independant of the planting distance. A maximum of $56 \mathrm{~m}^{3} / \mathrm{ha}$ was recorded for the second circle, and $26 \mathrm{~m}^{3} /$ ha for the outermost circle.

Previous results and circumferences are based on diameter measurements taken in the N/S direction. This means that for diverse reasons, there is an underestimation of the

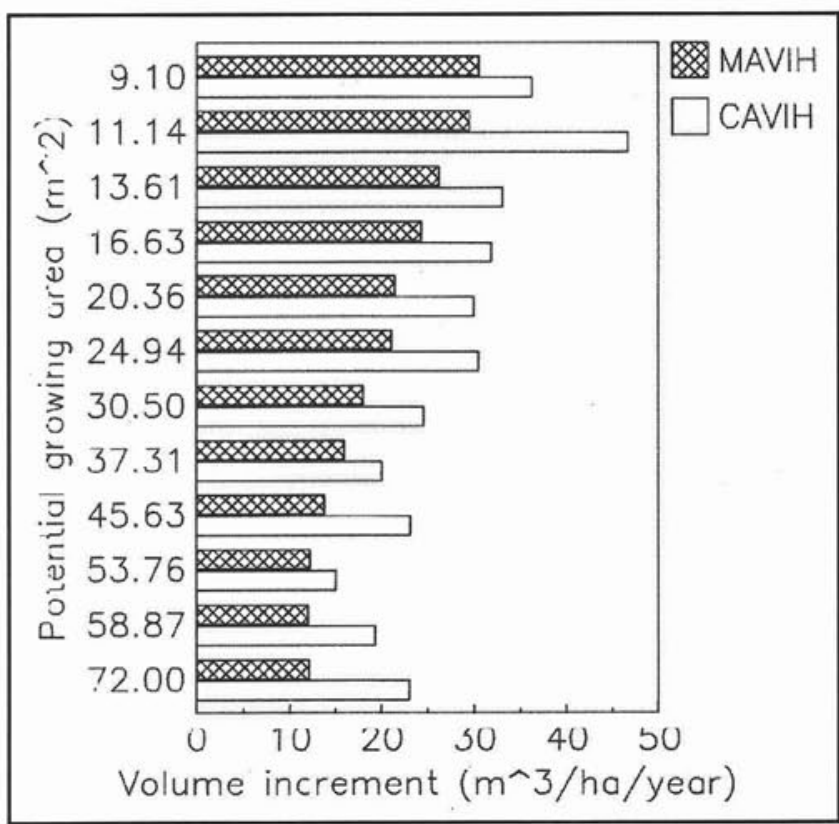

Figure 2. Mean volume increment (MAVIH) versus current volume increment (CAVIH), at a TC of $30 \mathrm{~cm}$, and at age 12, for different spacings

actual standing volume, generally used to judge a plantation and its productivity. In the first place, the calculation of a circumference from a diameter measurement will result in a smaller figure than that obtained from a circumference measurement itself. Thus we also get a smaller volume. Secondly, and for the same reason, a stem will be cross-cut at a lower height if we base the determination of the TC on a diameter measurement. And finally the standing volume of our plantation was underestimated by discounting the volume occupied by bark. The average volume percentage of bark (Table 1) amounts to $9.4 \%$. Table 1 also presents the stem volumes per hectare, calculated from circumference measurements with bark, for different planting distances, and two top circumferences, at age 12 .

At a TC of $30 \mathrm{~cm}$ and a PGA of $9.10 \mathrm{~m}^{2}$ a stem volume of $436 \mathrm{~m}^{3} / \mathrm{ha}$ was reached; at a TC of $70 \mathrm{~cm}$, this volume declined to only $66 \mathrm{~m}^{3} / \mathrm{ha}$. At a PGA of $72.00 \mathrm{~m}^{2}$, these yields were respectively $174 \mathrm{~m}^{3} / \mathrm{ha}$ and $154 \mathrm{~m}^{3} / \mathrm{ha}$.

\section{Dry Matter Productions per Hectare after 12 Years}

The productivity of a plantation can also be expressed in tons of dry matter per hectare. During this trial we restricted ourselves to stem dry matter production (without bark). Table 1 shows the dry matter production in tons per hectare to a TC of $30 \mathrm{~cm}$. At a PGA of $9.10 \mathrm{~m}^{2}$, a dry matter production of 134 tons/ha was reached, and at a PGA of $72.00 \mathrm{~m}^{2}, 51$ tons/ha.

\section{Comparison with Other Available Results and Expectations}

For decades, foresters in Western Europe experimented with the old euramerican poplar clones, such as 'Robusta', 'Serotina', 'I-214', etc., at smaller planting distances, e.g. 6 $\times 6 \mathrm{~m}$ and smaller. However, their extreme sensitivity to between-tree competition and to various leaf diseases, 
more specifically to rusts and Dothichiza populea, often caused an early death (Markovic and Roncevic 1992), so that these clones were not suited for plantations at smaller planting distances (Steenackers V. 1979).

Barnéoud and Bonduelle (1979) reported that "old" euramerican clones, such as 'I-214', 'Blanc du Poitou' and 'I 45-51' were no longer of importance, for use in shortrotation culture.

Jobling (1990) advised that euramerican poplar clones should be planted at distances between 7.5 and $8 \mathrm{~m}$ for growing veneer butts on rotations of approximately 25 years. Growing pulp wood or other fibre to maximise yield per hectare of utilizable stems $(10-20 \mathrm{~cm}$ d.b.h. $)$ on rotations of $10-15$ years at $2-3 \mathrm{~m}$ spacing is, according to Jobling, appropriate for clones or hybrids of $P$. trichocarpa which are more tolerant of competition at close spacing. Bonduelle (1989), on the other hand, mentions that the $P$. $\times$ trichocarpa 'Fritzi Pauley' will not be used any longer for the short-rotation culture in France. Five interamerican poplar clones, namely 'Beaupré', 'Boelare', 'Hunnegem', 'Raspaille', and 'Unal', all selected at the I.F.G.M. in Belgium, will be recommended and used for this purpose. He also reports the use of one euramerican clone, 'Dorskamp'. Generally Bonduelle expects that in France short-rotation culture (three rotations of $7-8$ years each, 2000 trees per hectare) with mostly interamerican poplar clones will be able to produce 25 - 30 tons fresh matter, or $11.25-13.50$ tons dry matter per hectare and per rotation, with the following dendrometrical specifications: a diameter at breast-height of $14 \mathrm{~cm}$, a total length of $15-17 \mathrm{~m}$, a volume of $0.100-0.150 \mathrm{~m}^{3}$ per tree, and a fresh weight of $70-100 \mathrm{~kg}$ per tree.

Tabresse and Schmitz (1991) reported results, achieved after 8 years with a short-rotation plantation, on a nonideal site for poplar, of the clones 'Beaupré' and 'Boelare' at a spacing of $4 \times 4 \mathrm{~m}$ (625 trees/ha). They determined the average tree, without making distinction between both clones, having a circumference at breast-height of $60 \mathrm{~cm}$, a timber height of $10.2 \mathrm{~m}$, a volume of $0.205 \mathrm{~m}^{3}$ and a fresh weight of $150 \mathrm{~kg}$ to a top diameter of $7 \mathrm{~cm}$. This means approximately $125 \mathrm{~m}^{3} /$ ha and 90 tons/ha. They also reported the vigourous growth of this plantation during the last three years and therefore suggest that the plantation could have grown for at least two more years, before a second rotation was started.

The model-tree grown at circle 4 (601 trees/ha), under different climatic and soil conditions, had, after 8 years, a circumference at breast-height of $64 \mathrm{~cm}$, a timber height of $10.0 \mathrm{~m}$, and a volume of $0.255 \mathrm{~m}^{3}$ to a top circumference of $30 \mathrm{~cm}$, or $153 \mathrm{~m}^{3} /$ ha.

Christersson (1992) expects for plantations in Sweden with selected poplar clones, among them interamerican clones selected in Belgium, in a total rotation time of 30 years, including thinnings, with 5000 trees per hectare, an annual dry matter production of 10 - 20 tons per hectare.

Goossens et al. (1990) have constructed yield tables for the clone 'Beaupré', at a spacing of $8 \times 8 \mathrm{~m}$ (156 trees per ha). Results are given, up to an age of 12 years, in Figure 3 for three different site indices and are compared with the results at circle 11 (170 trees per ha) and circle 12 (139 trees per ha) of the Nelder plantation at Kaulille. Curves obviously are different.

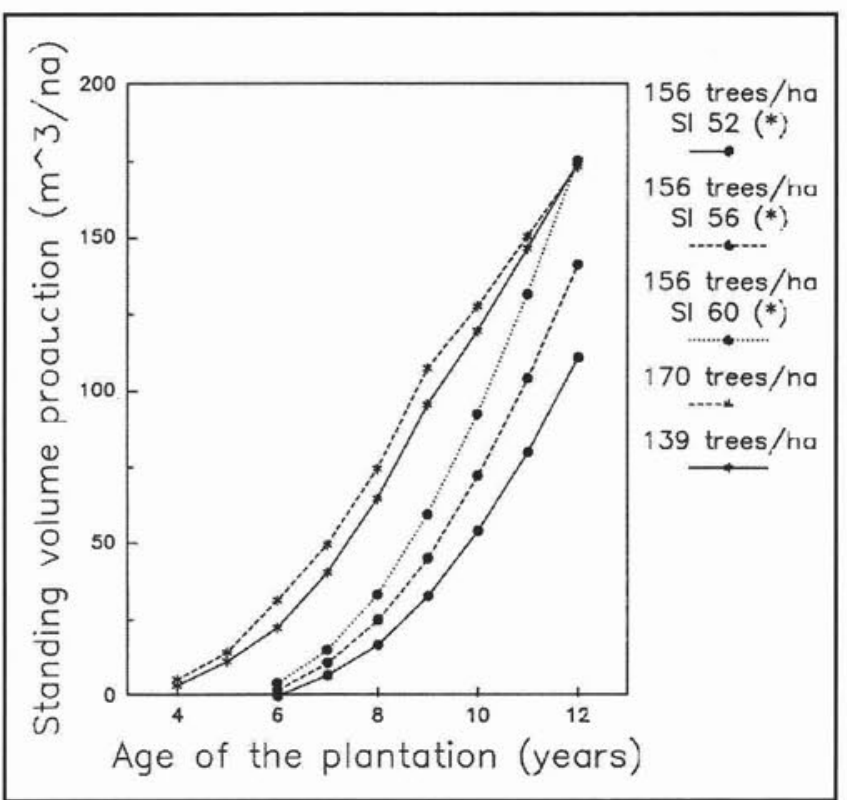

Figure 3. Comparison of results obtained in the Nelder plantation, with results calculated from analytic models (Goossens et al. 1990) $\left({ }^{*}\right)$

\section{Conclusions}

From this twelve-year-old Nelder design plantation, it appears that with fast growing interamerican poplar clones, such as 'Beaupré', very high volume production can be reached. Such high volume production obtained at different planting distances with the interamerican poplar clones are only possible because these clones are subjected to a pronounced heterosis effect, and because they are very resistent to the various leaf diseases and Dothichiza populea.

Even at a planting distance of $3 \times 3 \mathrm{~m}$ the current annual volume increment obtained during the 12 th growing season exceeded the mean annual volume increment : $\mathrm{PGA}=9.10$ $\mathrm{m}^{2}$, MAVI $=36 \mathrm{~m} 3 / \mathrm{ha} /$ year or 11 tons dry matter/ha/year (clean wood, without bark).

It is necessary to follow the growth of this experimental plantation annually in order to determine for every planting distance the right time of thinning, so that the growingrhythm of the remaining trees will not be disturbed. After some years it will be possible to give actual production figures for different clones, planting distances and diameteror circumference classes (thinnings and final cut). In relation to these classes, every class having its own selling price, the produced timber will be used as a raw material for different industrial applications, ranging from wood for pulp, paper and chips, to timber for boxes and pallets, to high quality timber for veneer.

By means of actual volume or dry matter production figures and selling prices, it will be possible to predict the economical and financial feasibility of such an intensive wood production system.

\section{References}

Barnéoud, Cl., P. Bonduelle. 1979. La culture du peuplier. Afocel, Paris, France. 274 p.

Bonduelle, P. 1989. Sylviculture du peuplier en taillis à courtes 
rotations. Afocel/Nord-Ouest, Trélazé, France. $41 \mathrm{P}$.

Christersson, L. 1992. The swedish programme for intensive short-rotation forest. Paper presented at the 19th Session of the International Poplar Conference - Zaragoza. 4 p.

Faber, P.J. 1985. Growth and spacing of 'Rap' poplar in a Nelder experiment. Nederlands Bosbouw Tijdschrift 57(5/6): 157-166.

Goossens, R., V. Steenackers, J. Van Slijcken. 1990. Provisional yield levels of the Unal poplar clones : 'Primo', 'Ghoy', 'Gaver' and 'Beaupré'. Poplar Research Center, Geraardsbergen, Belgium. 17 p.

Jobling, J. 1990. Poplars for wood production and amenity. Bulletin 92. Forestry Commission, Alice Holt Lodge, Wrecclesham, Farnham, Surrey, Great Britain. 84 p.

Markovic, J., S. Roncevic. 1992. Influence of spacing - plantation density of Populus euramericana cl. I-214 on rotation length. Paper presented at the 19th Session of the International Poplar Conference - Zaragoza. 14 p.

Nelder, J.A. 1962. New kinds of systematic designs for spacing experiments. Biometrics 18.3: 283-307.
Schalck, J., A. Caluwe, J. Lejeune, L. Meiresonne, A. Van Mieghem. 1977 - 1983. De biomassa als natuurlijke grondstof voor de productie van energie. Reports 1 - 6. Laboratories of Plant Ecology and Wood Technology, University Ghent, Belgium.

Smith, J.H.G. 1978. Design factors from Nelder and other spacing trials to age 20. Common For. Rev. 57(2): 109-119.

Steenackers, J., J. Van Acker, M. Stevens. 1992. Eindrapport over de werkzaamheden van Xylindus V.Z.W. gedurende de periode 1988-1992. Xylindus V.Z.W., Laboratory of Wood Technology, University Ghent, Belgium. 229 p.

Steenackers, M. 1991. The phytosanitary state of poplars in Belgium in 1991. Parasitica 47(2/3): 129-136.

Steenackers, V. 1979. Inlichtingen voor de populierenplanters. 24 p. Poplar Research Centre, Geraardsbergen, Belgium.

Tabresse, L., P. Schmitz. 1991. Excursions dans les champs d'essai de la Cellulose des Ardennes. ASBL Promotion et Culture, Arlon, Belgium. 4 p.
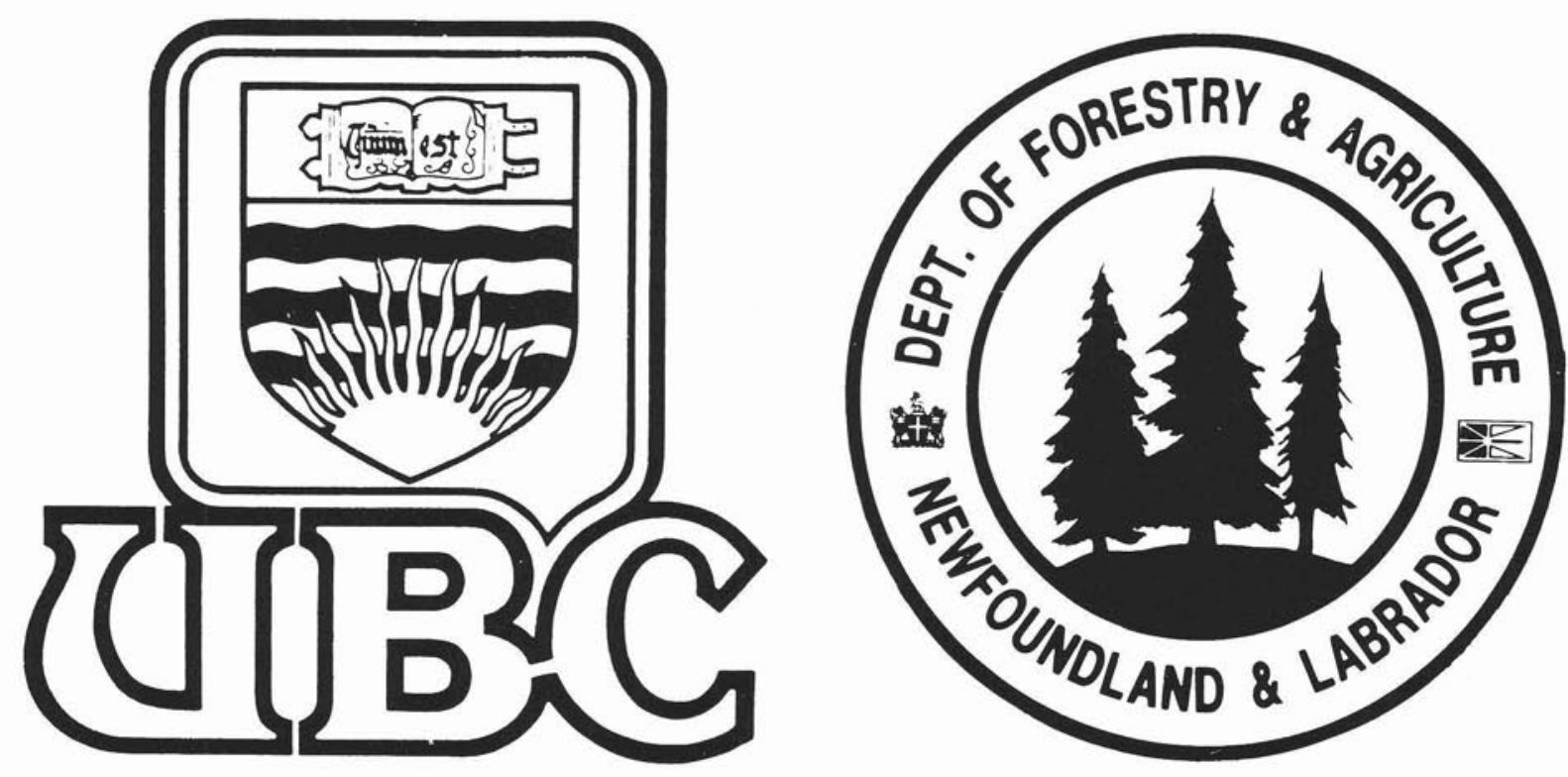

CIF/IFC Corporate Sustaining Members 